\title{
Underrepresentation of women in the senior levels of Brazilian science
}

\author{
Jaroslava V. Valentova ${ }^{1}$, Emma Otta ${ }^{1}{ }^{\text {, }}$, Maria Luisa Silva ${ }^{\text {Corresp., }}{ }^{2}$, Alan McElligott ${ }^{3}$ \\ 1 Department of Experimental Psychology, Institute of Psychology, University of Sao Paulo, Sao Paulo, Brazil \\ 2 Instituto de Ciências Biológicas, Laboratório de Ornitologia e Bioacústica, Universidade Federal do Pará, Belém, Pará, Brazil \\ 3 Biological and Experimental Psychology, School of Biological and Chemical Sciences, Queen Mary University of London, London, United Kingdom \\ Corresponding Author: Maria Luisa Silva \\ Email address: mluisa@ufpa.br
}

Despite significant progress, there is still a gender gap in science all over the world, especially at senior levels. Some progressive countries are recognizing the need to address barriers to gender equality in order to retain their best scientists and innovators, and ensure research excellence and social and economic returns on the investment made by taxpayers each year on training women scientists. We investigated the gender distribution of: (i) the productivity scholarship (PS) holders of the Brazilian National Council for Scientific and Technological Development (Conselho Nacional de Desenvolvimento Científico e Tecnológico, CNPq, N=13,625), (ii) the members of the Brazilian Academy of Science (Academia Brasileira de Ciências, ABC, N=899), and (iii) the amount of funding awarded for top quality research ("Universal" Call of CNPq, N=3,836), between the years of 2013 and 2014. Our findings show evidence for gender imbalances in all the studied indicators of Brazilian science. We found that female scientists were more often represented among PS holders at the lower levels of the research ranking system (2). By contrast, male scientists were more often found at higher levels ( $1 \mathrm{~A}$ and $1 B$ ) of PS holders, indicating the top scientific achievement, both in "Engineering, Exact Sciences, Earth Sciences", and "Life Sciences". This imbalance was not found in Humanities and Social Sciences. Only $14 \%$ of the $A B C$ members were women. Humanities and Applied Social Sciences had a relatively low representation of women in the Academy (3.7\%) compared to Engineering, Exact and Earth Sciences: $54.9 \%$ and Life Sciences: $41.4 \%$. Finally, female scientists obtained significantly more funding at the lower level of the research ranking system (2), whereas male scientists obtained significantly more funding at the higher levels (1A and 1B). Our results show strong evidence of a gender imbalance in Brazilian science. We hope that our findings will be used to stimulate reforms that will result in greater equality in Brazilian science, and elsewhere. 
2

\title{
Underrepresentation of Women in the Senior Levels of Brazilian Science
}

\author{
Jaroslava V. Valentova
}

Address: Department of Experimental Psychology, Institute of Psychology, University of São Paulo, Av. Prof. Mello Moraes, 1721, Sao Paulo, Brazil, CEP 05508-030

jaroslava@,usp.br

Emma Otta

Address: Department of Experimental Psychology, Institute of Psychology, University of São Paulo, Av. Prof. Mello Moraes, 1721, Sao Paulo, Brazil, CEP 05508-030 emmaotta@gmail.com

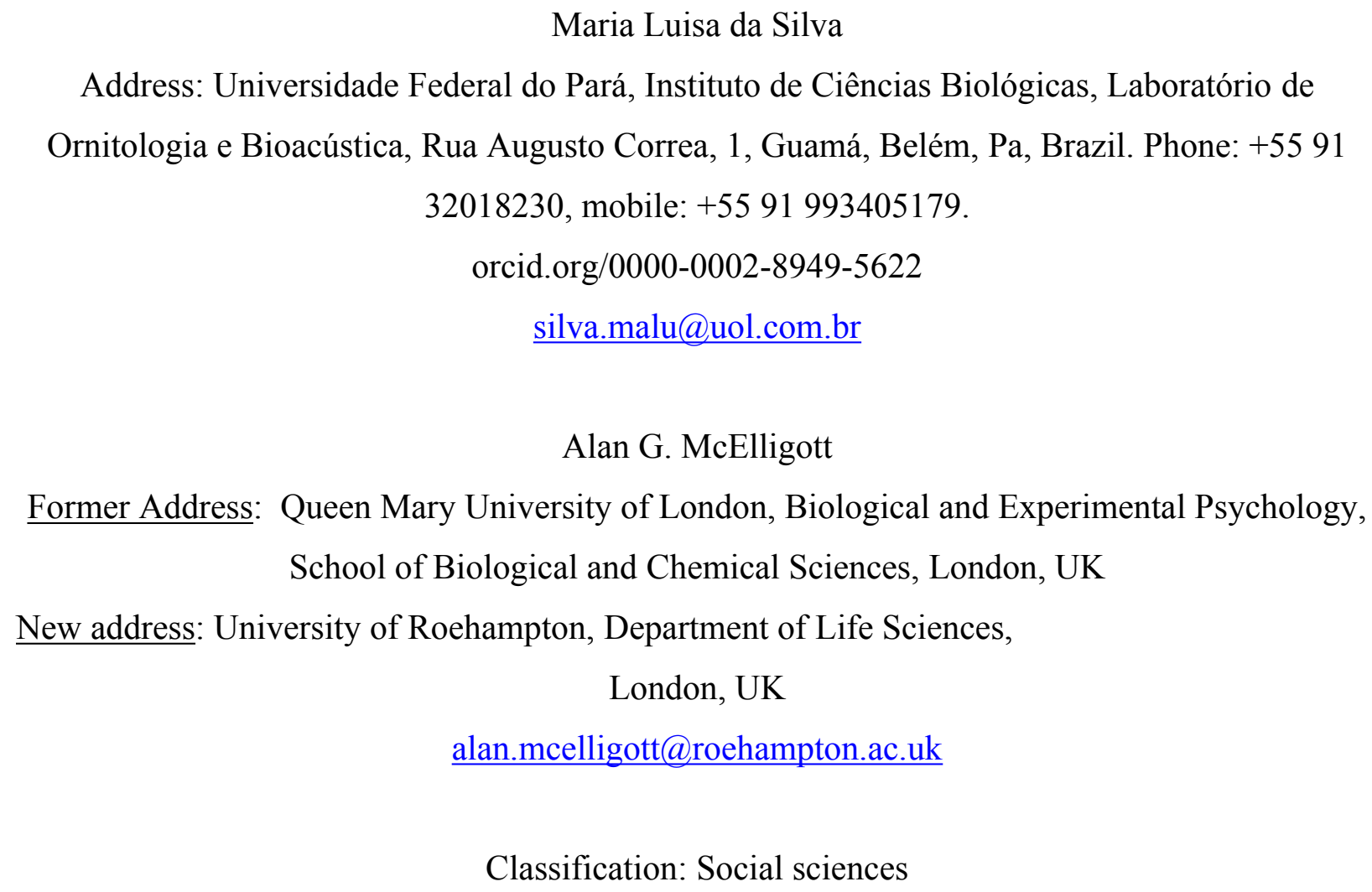




\section{Abstract}

1 Despite significant progress, there is still a gender gap in science all over the world, especially at senior levels. Some progressive countries are recognizing the need to address barriers to gender equality in order to retain their best scientists and innovators, and ensure research excellence and social and economic returns on the investment made by taxpayers each year on training women scientists. We investigated the gender distribution of: (i) the productivity scholarship (PS) holders of the Brazilian National Council for Scientific and Technological Development (Conselho Nacional de Desenvolvimento Científico e Tecnológico, CNPq, N= 13,625), (ii) the members of the Brazilian Academy of Science (Academia Brasileira de Ciências, $\mathrm{ABC}, \mathrm{N}=899$ ), and (iii) the amount of funding awarded for top quality research ("Universal" Call of CNPq, N=3,836), between the years of 2013 and 2014. Our findings show evidence for gender imbalances in all the studied indicators of Brazilian science. We found that female scientists were more often represented among PS holders at the lower levels of the research ranking system (2). By contrast, male scientists were more often found at higher levels (1A and 1B) of PS holders, indicating the top scientific achievement, both in "Engineering, Exact Sciences, Earth Sciences", and "Life Sciences". This imbalance was not found in Humanities and Social Sciences. Only $14 \%$ of the ABC members were women. Humanities and Applied Social Sciences had a relatively low representation of women in the Academy (3.7\%) compared to Engineering, Exact and Earth Sciences: 54.9\% and Life Sciences: 41.4\%. Finally, female scientists obtained significantly more funding at the lower level of the research ranking system (2), whereas male scientists obtained significantly more funding at the higher levels (1A and 1B). Our results show strong evidence of a gender imbalance in Brazilian science. We hope that our findings will be used to stimulate reforms that will result in greater equality in Brazilian science, and elsewhere. 


\section{Introduction}

Although some progress has been made, there is evidence of a persistent gender gap in science (1), (see a special 2013 issue of the journal Nature: nature.com/women; 2-3). All over the world, many women are deterred from pursuing a career in science to the most senior levels. Women scientists are still promoted less, win fewer grants, and are more likely to leave research than similarly qualified men. Whereas around half of those who gain doctoral degrees in science and engineering in the United States and Europe are women, only one-fifth of full professors are women (4).

Women represent less than $12 \%$ of the membership of the world's national science academies, according to a study conducted by the Academy of Science of South Africa (ASSAf; 5). An analysis of 69 National Science Academies revealed that the average proportion of members who were women stood at just $12 \%$ in 2013-14. Women were relatively more represented in the Academies of North America, Latin America and the Caribbean, with the Cuban Academy of Sciences having the highest proportion of female members (27\%). Examining the membership of the science academies of Brazil, China, France, and the USA according to gender, it was found that the percentage of women varies between 6 and 14\% (China 6\%, France 11\%, USA 13\%, Brazil 14\%; 5).

Some progressive countries have recognized the need to address barriers to gender equality in order to retain their best scientists and innovators, and to ensure research excellence. Policies that focus on gender equality in science would also assist with making sure that social and economic returns on the investments made by taxpayers each year on training women scientists are not wasted. The Athena SWAN Charter is an accreditation and improvement program for higher education and research organizations focusing on gender and other forms of inequality, which was established in the UK in 2005 (6,7). This program is proving successful in improving gender equality in terms of promotion and retention of women in science (7). Similarly, in Australia, the Science in Australia Gender Equity (SAGE) was created in 2015 in order to address problems related to gender equality (8). SAGE is an initiative of the Australian Academy of Science in partnership with the Australian Academy of Technological Sciences and Engineering, and was adapted from the Athena SWAN Charter (7). 
84

85

86

87

88

89

90

91

92

93

94

95

96

97

Innovative national policies that affect research funding include gender balance targets (e.g. Slovenia, Switzerland) and legislation on gender quotas of up to $40 \%$ of the minority gender on committees (e.g., Finland, Norway). Some countries also have policies to increase university funding based on their performance in terms of gender equality (e.g., Ireland, Germany and Netherlands) (9).

\section{Gender gap in Brazilian science}

Recently, a large study aimed at research performance (mainly production of papers) over past 20 years in a number of world regions conducted by Elsevier (10) reported that during the period between 2011-2015 nearly half (49\%) of Brazilian scientific studies were produced by women. This is in a sharp contrast with the period of 1996-2000, when women contributed with only $38 \%$ of the Brazilian scientific production. Thus, together with Portugal (that showed similar recent changes), Brazil is one of the countries closing the gender gap in scientific production.

However, although Brazilian women publish recently as much as men, and although some scientific areas (for example, Biology and Humanities) are represented more by women students (11), the gender ratio among the top scientific positions tells a different story. One way how to investigate gender composition among the top professional scientific positions in Brazil is to analyse the distribution of productivity scholarships provided by the Brazilian National Council for Scientific and Technological Development (Conselho Nacional de Desenvolvimento Científico e Tecnológico - CNPq).

CNPq is a funding agency of the Brazilian federal government. It was created in 1951 and is dedicated to the promotion of scientific and technological research, as well as the creation of human resources for research (12-13). It also plays a major role in the formulation and implementation of science, technology and innovation policies in Brazil. CNPq offers several levels of highly competitive scholarships, such as monthly scholarships for students at graduate and postgraduate degrees, and also Productivity Scholarships (PS) aimed at "researchers who stand out among their peers, according to their scientific production". Among the candidates, CNPq selects proposals for financial support that are likely to contribute significantly to the scientific and technological development and innovation in any area of knowledge for Brazil. The requests are evaluated by 66 committees within the three big areas of CNPq equivalent to 
115 STEM Science with more than 300 members. Researchers are classified into Category 1 (at least 1168 years after receiving $\mathrm{PhD}$ ) and Category 2 (at least 3 years after receiving $\mathrm{PhD}$ ). Within

117 Category 1, a researcher is classified in one of four different levels (1A, 1B, 1C or 1D), based on

$118 \mathrm{his} /$ her scientific output (peer-reviewed journal articles, books and book chapters), scientific

119 coordination of research networks, and contribution to human resources creation (theses

120 supervisions of $\mathrm{MSc}$ and $\mathrm{PhD}$ students, and supervision of undergraduate research students)

121 during the previous 10 years. The four levels present a decreasing order of prestige and value.

122 Thus, the researcher $1 \mathrm{~A}$ is classified at the highest possible range of scientific research according

123 to the ranking system of the country. There is no level specification for category 2 , and the

124 researcher's productivity is evaluated by his/her publications and student supervisions during the

125 last five years. All researchers start at the category 2 level, and ask for reclassification after three

126 years of their work. The classification between category 1 and 2, which depends on years after

127 receiving $\mathrm{PhD}$, does not take into account maternity leave (four or six months) or any other

128 career breaks.

129 There is a lot of research on Productivity Scholarship Holders (PSH) of CNPq, focused

130 on specific sub-areas of knowledge. Recent studies in Chemistry (14), Odontology (15), Physical

131 Education (16), Veterinary Medicine (17) and Medicine (18-20) show that PSH researchers are

132 predominantly men (60-76\%). In these areas, men also receive the majority (around 56\%) of

133 Category 2 grants. In Pediatrics (21) and Cardiology (22), a similar pattern was found, as in the

134 whole of Medicine. One decade earlier, when a slightly different system was used by CNPq to

135 classify PS researchers (1A, 1B, 1C, 2A, 2B, 2C), the profile of researchers in public health also

136 showed a clear gender gap (23). Whereas $1 \mathrm{~A}(\mathrm{PhD} \geq 21$ years), $1 \mathrm{~B}(\mathrm{PhD} \geq 20$ years) and $1 \mathrm{C}$

$137(\mathrm{PhD} \geq 14$ years) researchers were typically men, $2 \mathrm{~A}(\mathrm{PhD} \geq 12$ years) could be men or women,

138 and $2 \mathrm{~B}(\mathrm{PhD} \geq 9$ years $)$ and $2 \mathrm{C}(\mathrm{PhD} \geq 6$ years) were typically women $(23)$.

139 An analysis of CNPq's database in 2002 revealed that Brazilian women made up a larger

140 proportion of junior student positions than men (e.g. undergraduate Scientific Initiation

141 Scholarships and Masters Scholarships), but were less represented than men in the most senior

142 professional roles (e.g. Productivity Scholarships; 24): Scientific Initiation Scholarship (55\% of

143 14,040), Masters Scholarships (53\% of 5,592), PhD Scholarships (48\% of 5,734), Postdoctoral

144 Fellowships (50\% of 376), Productivity Scholarships (32\% of 7,763). A proportion of the women

145 that go through the early stages of scientific careers are therefore "lost" along the way, or simply 
146 do not get the recognition from peers to continue to conduct research with grants (24). However,

147 the gender gap seems to be reversed in some fields. For example, in 2013 among Psychology the 148 majority of PSH researchers were women (63\%) across all the ranking levels (25).

149 Another way to study gender differences among Brazilian scientists is to analyse the 150 gender composition of the Brazilian Academy of Science (Academia Brasileira de Ciências $151 \mathrm{ABC})$. The $\mathrm{ABC}$ is a prestigious honorific scientific society, founded in 1916 (13). The most

152 important representatives of the Brazilian scientific community are admitted as members after a 153 rigorous selection process. They have a leadership role in the advancement of scientific and 154 technological activities of the country. ABC interacts with the federal government and its 155 agencies, identifying research priorities in several issues of national interest, focused on the 156 economic development and the well-being of the population. This contributes to new programs 157 and actions of the national policy of Science, Technology and Innovation. The supra-institutional 158 nature of $\mathrm{ABC}$, the leadership role and ample diversity in the areas of interests of its members 159 enable $\mathrm{ABC}$ to discuss and propose new solutions to scientific and socio-economic issues that 160 require a multidisciplinary approach.

\section{Aims of the Current Study}

Here, we studied the gender distribution of: (a) the productivity scholarship holders (PSH) of the Brazilian National Council for Scientific and Technological Development (CNPq; 26), (b) the members of the Brazilian Academy of Science (ABC; 27), and (c) the amount of funding awarded for research ("Universal" Call of CNPq; 28). We analysed the data according to gender, area of knowledge, and level in the research ranking system. More specifically, the goal of the present research was to offer a more comprehensive picture of gender imbalances in Brazilian science, by comparing the areas of Engineering, Exact Sciences, Earth Sciences, Life Sciences, and the Humanities and Applied Social Sciences. According to previous research, we expected a higher frequency of male researchers among scholarship holders and among the Academy of Science members. We also hypothesized that the gender gap would be less

172 pronounced in the fields of Humanities and Social Sciences compared to Exact Sciences. The 173 overarching goal of our research is to raise awareness of gender imbalance in science and 174 stimulate to future policy changes that address will this problem. 
175

176

177

178

179

180

181

182

183

184

185

186

187

188

189

190

191

192

193

194

195

196

197

198

199

200

201

202

203

204

205

\section{Materials and Methods}

The study sample included a total 13,625 productivity scholarship holders (PSH) of the Brazilian National Council for Scientific and Technological Development (CNPq); 4,859 from the area of Engineering, Exact Sciences, and Earth Sciences (ETEC), 5,687 from the area of Life Sciences (LS), and 3,079 from the area of Humanities and Applied Social Sciences (HASS), according to lists publicly available at the site of the agency at January 2016 (26). The study sample also included a total of 899 active members of the Brazilian Academy of Sciences according to lists organized by gender publicly available at the site of ABC at January 2016 (27). Their area of knowledge was identified according to Lattes curricula (unified system of academic information for Brazilian researchers and students), photos were checked, and CNPq research categories $(1 \mathrm{~A}, 1 \mathrm{~B}, 1 \mathrm{C}, 1 \mathrm{D}$, and 2) were determined for those who were productivity scholarship holders.

We analysed an additional sample of 3,836 researchers awarded funding for research in the UNIVERSAL MCTI/CNPQ CALL (№ 14/2014), comparing the results in the three funding ranges by gender: less than 30 thousand Brazil reals (BRL; 3.12 BRL = 1 US dollar, USD), 3060 thousand BRL and 60-120 thousand BRL. The call was open to all scientific disciplines and types of research, from basic research to applied research, including scientists who are not PS holders. Researchers with $\mathrm{PhD}>7$ years ago could apply for the lower funding range $(<\mathrm{BRL}$ $30,000=\mathrm{USD} 9,619)$. The intermediate funding range $(<\mathrm{BRL} 60,000=\mathrm{USD} 19,240)$ was open to Level 2 researchers. Level 1 PS holders could only submit proposals to the higher funding range $(<$ BRL $120,000=$ USD 38,480).

\section{Statistical analysis}

Separate datasets were created for Engineering, Exact Sciences and Earth Sciences (ETEC), Life Sciences (LS), and Humanities and Applied Social Sciences (HASS) productivity scholarship holders, for researchers awarded funding and for members of the Brazilian Academy of Science. The datasets were constructed with information on gender, sub-area of knowledge, level of research category $(1 \mathrm{~A}, 1 \mathrm{~B}, 1 \mathrm{C}, 1 \mathrm{D}, 2)$ and amount of funding. Categorical (dichotomous or nominal) variables were compared using the chi-square test in SPSS 20.0.

To explore possible effect of generation on gender differences, we analysed age distribution of the $\mathrm{ABC}$ members. Age distribution of the $\mathrm{ABC}$ members (full members, 
206

207

208

209

210

211

212

213

214

215

216

217

218

219

220

221

222

223

224

225

associated members and others ranged from 30 to 102 years, with the mean of 66.05 years $(\mathrm{SD}=$ 15.96). The histogram showed two peaks in the age distribution, at approximately 40 and 70 years old. Thus, we divided the sample into two categories, 30-50 ( $\mathrm{N}=178)$, and more than 50 $(\mathrm{N}=779)$, to explore whether there might be a generation effect on the gender distribution.

We used a Crosstabs procedure to test the independence of two categorical variables. If the chi-square was significant, indicating an association among the variables, but the table was larger than $2 \times 2$, we requested the adjusted standardized residuals from among the options in the Cells dialog (or /CELLS subcommand). Adjusted residuals are interpreted in the following way: under the null hypothesis that the 2 variables are independent, the adjusted residuals will have a standard normal distribution, i.e. have a mean of 0 and standard deviation of 1 . Therefore, an adjusted residual that is more than 1.96 (2.0 is used by convention) indicates that the number of cases in that cell is significantly larger than would be expected if the null hypothesis was true, with a significance level of .05 . An adjusted residual that is less than -2.0 indicates that the number of cases in that cell is significantly smaller than would be expected if the null hypothesis were true. Thus, the standardized residual shows whether there are fewer or more cases (depending on the sign of the adjusted residual) than would be expected if the 2 variables were independent. It is worth noting that the results are not based on expectation of $50 \%$ of women in each category, but calculation of each case of the expected value is based on the total of rows, total of columns and on the general $\mathrm{N}$ according to the chi-square test. 
232

233

234

235

236

237

238

239

240

241

242

243

244

245

246

247

248

249

250

251

252

253

254

255

\section{Results}

For the CNPq's productivity scholarship holders, we found that women are involved in all areas of research, but equally represented only in Humanities and Applied Social Sciences $\left(50 \%, \chi^{2}=0.094, \mathrm{~N}=3,079, \mathrm{df}=1, \mathrm{p}=0.75\right)$, compared with Life Sciences $(41 \%, \mathrm{~F} \chi 2=$ 171.992, $\mathrm{N}=5,687, \mathrm{df}=1, \mathrm{p}<0.001)$ and Engineering, Exact and Earth Sciences $(20 \%, \chi 2=$ 1739.17, $\mathrm{N}=4,859, \mathrm{df}=1, \mathrm{p}<0.001)$.

\section{Gender distribution of productivity scholarship holders in sub-areas of knowledge}

There are significantly fewer women than expected by chance in some sub-areas of Engineering, Exact and Earth Sciences, $(\chi 2=267.05, \mathrm{df}=21, \mathrm{p}<0.001)$. The adjusted residuals revealed that the number of women was smaller than expected in the sub-areas of Biomedical Engineering, Electrical Engineering, Mathematics, Mechanical Engineering, and Physics, but was greater than expected in Chemical Engineering, Chemistry, Industrial Design, Materials Engineering, Nuclear Engineering, Oceanography Production Engineering and Sanitary Engineering (Table 1, for details see, Table 2).

A significant association was found between gender and the sub-areas of Life Sciences $(\mathrm{CV}),\left(\chi^{2}=788.70, \mathrm{df}=29, \mathrm{p}<0.001\right)$. The number of women was smaller than expected by chance in Agricultural Engineering, Agronomy, Biophysics, Fisheries Engineering, Forest Engineering, Physical Education, Veterinary Medicine, Zoology, Zootechnology, but was greater than expected in Biochemistry Botany, Food Science and Technology, Genetics, Immunology, Microbiology, Morphology, Nursing, Nutrition, Pharmacology, Pharmacy, Phonoaudiology, Physiotherapy and Public Health (Table 1, see also Table 3).

There was also a significant association between gender and the sub-areas of Humanities and Applied Social Sciences (HASS), $\left(\chi^{2}=360.06, \mathrm{df}=23, \mathrm{p}<0.001\right)$. The number of women was smaller than expected by chance in Administration, Economics and Philosophy, but was greater than expected in Arts, Education, Information Science, Linguistics, Psychology and Social Services (Table 1, see also Table 4).

\section{Distribution of productivity scholarship holders by gender and scholarship level}


There was a significant association between gender and scholarship level in Engineering,

257 Exact Sciences and Earth Sciences $(\chi 2=45.70, \mathrm{df}=4, \mathrm{p}<0.001)$, Life Sciences $(\mathrm{CV} ; \chi 2=$

258 89.20, $\mathrm{df}=4, \mathrm{p}<0.001)$, and Humanities and Applied Social Sciences (CHSA; $\chi 2=13.78, \mathrm{df}=$

$2594, \mathrm{p}<0.01)$. In ETEC and LS, the number of women was greater than expected in the lower level

260 of the research ranking system, whereas the number of men was greater than expected in the

261 higher levels (1A and 1B; Table 4). A different pattern was found in HASS, with a smaller

262 gender gap in the research ranking system (Table 4).

263 In Engineering, Exact Sciences and Earth Sciences, the proportion of men was higher in

264 Chemistry $(\chi 2=16.38, \mathrm{df}=4, \mathrm{p}<0.01)$, Civil Engineering (Fisher's Exact Test $=16.24, \mathrm{p}<$

265 0.01), and Sanitary Engineering (Fisher's Exact Test $=9.89, \mathrm{p}<0.05$ ). In Life Sciences the

266 proportion of men was higher in Medicine $(\chi 2=23.78, \mathrm{df}=4, \mathrm{p}<0.001)$, Public Health $\left(\chi^{2}=\right.$

267 18.85, df = 4, p < 0.001), Physiology (Fisher's Exact Test $=26.22, \mathrm{p}<0.001$ ), Agronomy

268 (Fisher's Exact Test $=20.67, \mathrm{p}<0.05)$, Pharmacology $($ Fisher's Exact Test $=18.40, \mathrm{p}<0.001)$,

269 Odontology (Fisher's Exact Test $=11.82, \mathrm{p}<0.05$, and Botany (Fisher's Exact Test $=10.50, \mathrm{p}<$

270 0.05). In Humanities and Applied Social Sciences, significant associations between gender and

271 scholarship level were found for Psychology (Fisher's Exact Test $=61.76, \mathrm{p}<0.001$ ) and Urban

272 Planning (Fisher's Exact Test $=15.26, \mathrm{p}<0.01$ ), with more women than expected by chance in

273 the intermediate levels of the research ranking system, PS-1B and PS-1C.

274

\section{Gender distribution of the Brazilian Academy of Science}

There were 126 female members $(14 \%)$ of the Brazilian Academy of Science $\left(\mathrm{ABC} ; \chi^{2}=\right.$

465.64, $\mathrm{N}=899, \mathrm{df}=1, \mathrm{p}<0.001)$. Examining the gender distribution as a function of areas of knowledge, using the classification of the National Council for Scientific and Technological Development $(\mathrm{CNPq})$, the gender gap is more pronounced in Engineering, Exact and Earth Sciences (8.9\%), and less pronounced in Life Sciences (20.4\%), and Humanities and Applied Social Sciences $(18.2 \%),(\chi 2=23.87, \mathrm{~N}=899, \mathrm{df}=1, \mathrm{p}<0.001)$. Male scientists predominate in all areas of knowledge, and the representation of Humanities and Applied Social Sciences in the academy is low (Table 5).

The percentage of women in the Brazilian Academy of Sciences does not correspond to the percentage of women among Productivity Scholarship Holders; it is two times lower. This occurs in all areas of knowledge (Figure 1). For Brazilian Academy of Science members who 
287 were Productivity Scholarship Holders, there was a significant association between gender and 288 scholarship level in Life Sciences (Fisher's Exact Test $=10,08, \mathrm{p}<0.05$ ), but not in Engineering, 289 Exact Sciences and Earth Sciences $(\chi 2=4,765, \mathrm{df}=4$, NS). The small sample size in Humanities

290

291

292

293

294

295

296

297

298

299

300

301

302

303

304

305

306

307

308

309

310

311

312 and Applied Social Sciences precludes detailed analyses. However, in LS, the number of women was greater than expected in the lower level of the research ranking system (1D), whereas the number of men was greater than expected in the higher level (1A, Table 6).

When divided into two age categories (30-50 and $>50$ years), there was a significant gender difference in both age categories in Engineering, Exact and Earth Sciences, and Life Sciences, and a significant difference between men and women in Humanities and Applied Social Sciences (Table 7). When we compared the proportions of women between the younger and the older category, we found a significant difference in the total number of women $\left(\chi^{2}=\right.$ $22.35, \mathrm{df}=1, \mathrm{p}<0.001)$, and also specifically in Engineering, Exact and Earth Sciences $\left(\chi^{2}=\right.$ 8.22, $\mathrm{df}=1, \mathrm{p}<0.001)$, Life Sciences $\left(\chi^{2}=11.87, \mathrm{df}=1, \mathrm{p}<0.001\right)$, while there was no difference in Humanities and Applied Social Sciences $(\chi 2=0.45$, df $=1, p=0.50)$.

\section{Amount of funding awarded by gender}

Analysing the amount of funding awarded by gender in the Universal CNPq Call, it was found that female scientists obtained more funding at the $\mathrm{BRL}<30,000$ range, whereas male scientists obtained more funding at the higher ranges, especially $\mathrm{BRL}<120,000$ (contingency chi-square test, $\chi^{2}=24.20, \mathrm{~N}=3,836, \mathrm{df}=2, \mathrm{p}<0.001$ ). An additional analysis of the amount of funding awarded by gender in the Universal CNPq Call, conducted separately by areas of knowledge (Table 8), showed that the association was significant in Life Sciences (contingency chi-square test, $(\chi 2=17.195, \mathrm{~N}=2,024, \mathrm{df}=2, \mathrm{p}<0.001)$, but not in Humanities and Applied Social Sciences, $(\chi 2=3.218, \mathrm{~N}=651, \mathrm{df}=2, \mathrm{NS})$, nor in Exact Sciences and Earth Sciences, $\left(\chi^{2}\right.$ $=2.277, \mathrm{~N}=1,161, \mathrm{df}=2, \mathrm{NS})$. 
313

314

315

316

317

318

319

320

321

322

323

324

325

326

327

328

329

330

331

332

333

334

335

336

337

338

339

340

341

342

343

\section{Discussion}

Our findings show gender imbalances in senior levels of Brazilian science, considering scientific productivity scholarships, grants and membership of Brazilian Academy of Sciences. Our analysis of a sample of 13,625 productivity scholarship holders (PSH) of the Brazilian National Council for Scientific and Technological Development (CNPq) showed that female scientists were more represented among PSH at the lower level of the research ranking system, whereas male scientists were more represented at higher senior levels (1A or 1B). This was evident in Engineering, Exact and Earth Sciences, and in Life Sciences. This result is in line with the gender gap in science found at senior levels worldwide (1, 4). In Brazil, the gender gap in science was reduced in Humanities and Social Science compared to Engineering, Exact and Earth Sciences, which has also been found in other countries such as the UK (9).

Our analysis of a sample of 3,836 researchers awarded funding by the Universal CNPq Call shows that female scientists were more frequently awarded lower amounts to conduct their research than male scientists. We did not have access to the amounts of funding requested by gender, and therefore we do not know if women applied for similar amounts. However, it is notable that there were no significant differences in the amount of funding awarded according to gender both in Humanities and Applied Social Sciences, and in Engineering, Exact and Earth Sciences, and Life Sciences. The smaller amount of funding awarded to female scientists was only found in Life Sciences ( $<30,000$ BRL versus $<120,000$ BRL). In Biomedical sciences, women also get smaller grants than men in the US (29) and the UK (30).

There are relatively more women members of the Brazilian Academy of Science (ABC) compared to other academies of science (27). Nevertheless our study revealed several asymmetries in ABC. For example, the proportion of men is greater in all areas of knowledge (Engineering, Exact and Earth Sciences: 8.9\% women (W) versus 91.1\% men (M), Life Sciences: 20.4\% W versus 79.6\% M; Humanities and Applied Social Sciences: 18.2\% W versus $81.8 \% \mathrm{M})$. The proportion of researchers working in Humanities and Applied Social Sciences is very low in the $\mathrm{ABC}(3.7 \%)$ in comparison to Engineering, Exact and Earth Sciences, and Life Sciences (54.9\% and $41.4 \%$, respectively). The proportion of women in the ABC is approximately half that of women among Productivity Scholarship Holders in all areas of knowledge (Exact Sciences and Earth Sciences: 8.9\% versus 19.8\%; Life Sciences: 20.4\% versus 41.3\%; Humanities and Applied Social Sciences: 18.2 versus 49.7\%). Finally, among members 
344 of the ABC who were Productivity Scholarship Holders of the area of Life Sciences, the number

345 of women was greater than expected in the lower level of the research ranking system (1D),

346 whereas the number of men was greater than expected in the higher level (1A). As can be

347 expected, most ABC members are holders of higher levels of PS, and thus the differences

348 between men and women points to the general finding of gender imbalance in the senior

349 academic positions. Our additional analyses including age of the ABC members support this

350 notion showing that the gender gap is smaller among a younger category of individuals.

351 Our results are in agreement with previous research showing that in several scientific

352 areas, in particular Exact Sciences, women are heavily underrepresented which can be result of

353 several factors (e.g., 31), such as women's self-exclusion from competition, and time out for

354 maternity leave. For example, the Brazilian system of classification of scientists by CNPq does

355 not take into account maternity leave (four or six months) or any other career breaks, which

356 could be one of the reasons for the expected reduction in women in the higher classification

357 levels, in particular at the beginning of their careers. In addition, the very fact of being in a

358 minority may make women more likely to drop out. Moreover, we can speculate that scientific

359 areas can be avoided by women because of great workloads and stress caused by such

360 professions that is incompatible with family life. However, this would be true also for other

361 areas, such as social sciences, veterinary medicine, medicine, or law where in some countries

362 women dominate (e.g., 32). One of the plausible factors seems to be competitiveness and job

363 insecurity in science (compared to medicine, for example, 32) that can be biased in many ways,

364 such as recommendation letters (33). In addition, and as supported by our data, it is important to

365 remember that there may be generational effects; if the more senior grades are people who

366 started careers a long time ago then there may have been different pressures and opportunities for

367 them.

368 Another major reason for gender imbalances in science is that women more commonly

369 tend to opt for areas such psychology and veterinary, while more men choose more traditional

370 areas, such as engineering (for a meta-analysis, see 34). This is due to many factors, such as

371 conditioning from early ages, or cognitive differences between men and women (that can be

372 caused by both biological and cultural factors; 34). However, cognitive differences between men

373 and women are quite small or even non-existent (for review see 35, 36), which means that most

374 men and women overlap greatly in their abilities. The effect size of sex difference in career 
375 preferences is, by contrast, large (34), which points to the fact that differences in cognition only

376 marginally contribute to the gender imbalance in academic representatives of many scientific

377 fields. Thus, public opinion and popular literature exaggerating "natural" sex differences in

378 cognition, and arbitrarily creating two distinct categories of men versus women can largely affect

379 expectations of representation of women in science. For example, women scientists represent a

380 minority in school science textbooks, and they are also invited less for conferences as plenary

381 speakers (2). Changing this might start to change the public opinion that women are less

382 competent for scientific jobs. Overall, a lack of role models and the public message of lack of

383 competency decreases self-esteem and motivation of women to compete with men in numerous

384 dimensions of scientific work, such as publications quantity (37). As suggested by Ceci and

385 Williams (31), it is highly important to offer to women "realistic information about career

386 opportunities and expose them to role models" to "ensure they do not opt out of inorganic fields

387 because of misinformation and stereotypes". Thus, early education should focus more on not

388 biased information about scientific fields, leaving misinformation based on social stereotypes

389 behind.

390 We show that there are great differences for women between Life Sciences and

391 Engineering and Exact Sciences (ETEC), versus the Humanities and Social Science. It seems

392 that during the career there is a significant drop of women in ETEC and most Life Sciences,

393 while the gender gap is not much pronounced on the senior level of Humanities and Social

394 Sciences. Again, this can be caused by many factors, similar to those discussed above. One study

395 (38) compared adherence of women in STEM in general and other professional positions,

396 showing that in many dimensions, such as family factors, these professional areas would be

397 comparable. However, factors such as job satisfaction and in general motivation to remain active

398 in the field, seem to be lower in STEM (38). Thus, the policy might focus on motivating women,

399 and creating more women-friendly environments in STEM professions to reduce the exit rate.

400 Our data from the Brazilian Academy of Science contains the age distribution of their

401 members. We were thus able to test whether the gender difference remains stable or changes

402 through the age cohorts. We showed significantly higher proportion of women among the

403 younger ABC members than among the older members. Thus, it seems that with lower age

404 groups the gender difference even in the top scientific levels tends to diminish. This is in

405 agreement with a new study showing that only recently Brazilian women publish half of the 
406 scientific papers, in comparison to the past (10). Although the situation seems to be improving, 407 still the gender difference in all the scientific areas was significant among the ABC members. 408 The Brazilian government has programs, such as Programa Pró-Equidade de Gênero e 409 Raça (39) [The Pro-Equity Gender and Race Program], and Observatório de Igualdade de 410 Gênero [Brazil Observatory of Gender Equality] (40). They focus on people management and 411 organizational culture to achieve equality between women and men in the labour market, 412 political participation, on reduction of violence against women, but not specifically on gender 413 inequality in science. The Brazilian Academy of Science has a leadership role in the country, 414 contributing to the policy of Science, Technology and Innovation. The achievements of Brazilian 415 women in science are discussed by the $\mathrm{ABC}$, recognizing the importance of retaining them and 416 making the best use of the investment made in training women scientists. Nevertheless, our 417 research clearly shows that even with more female presence than in other countries, the 418 imbalance is still evident.

419 Our research has several limitations. For example, we do not possess data on gender 420 balance in application for Productivity Scholarships and other research grants. Thus, the present 421 data do not show if lower numbers of women with grants are because fewer women apply, or 422 because those who do apply are less likely to be funded. Because this would be a key factor for 423 developing effective solutions to gender imbalance in science, future studies should focus on the 424 difference between applicants and funded researchers.

Future research might focus not only on mapping gender differences in scientific or any

426 other areas of human behavior, but also on specific mechanisms that lead to such gender gaps, 427 which might help to better understand and in particularly to reduce the gender gaps. For 428 example, Nosek et al. (41) analysed Implicit Association Tests completed by citizens of 34 429 countries and found that nation-level implicit stereotypes associating science with males more 430 than with females predicted nation-level sex differences in 8th-grade science and mathematics 431 achievement. They suggested that implicit stereotypes and sex differences in science 432 participation and performance are mutually reinforcing, and contributing to the persistent gender 433 gap in science engagement. Thus, the differences in top scientific levels are just the tip of an 434 iceberg that starts as early as during childhood with different expectations that the society has 435 from men and women. 
436 Overt sexism has decreased over the last few decades, but subtle gender biases maybe

437 still be exhibited by both men and women, and are held even by individuals who consider

438 themselves as egalitarian (42-44). Our results show clear evidence of imbalance of gender in

439 Brazilian science, and this probably has deep institutional and cultural roots. We agree with

440 Mühlenbruch and Jochimsen $(2013,45)$ that research policies are needed and only wholesale

441 reforms will bring equality to Brazil and other countries. The Athena Swan program in the UK

442 and similar initiatives in other countries provide important examples of how long-term progress

443 can be achieved $(7,8)$.

444

445 Acknowledgements

446 This paper resulted from a talk by Dr. Alan McElligott on the UK Athena Swan gender equality

447 program, at the XXXII Annual Meeting of Ethology in 2015, organized in Brazil by Prof. Maria 448 Luisa da Silva. 
450

451

452

453

454

455

456

457

458

459

460

461

462

463

464

465

466

467

468

469

470

471

472

473

474

475

476

477

478

\section{References}

1. Shen H (2013) Mind the gender gap Nature 495:22-24. Available at http://www.nature.com/news/specials/women/index.html. (Accessed March 11, 2016).

2. Martin JL (2014) Ten simple rules to achieve conference speaker gender balance PLOS Computational Biology 10(11) 1-3.

3. McAllister D, Juillerat J, Hunter J (2016) What stops women getting more grants? Nature 529466.

4. Handelsman J, Cantor N, Carnes M, Denton D, Fine E, Grosz B, Hinshaw V, Marrett C, Rosser S, Shalala D, Sheridan J (2005). More women in science. Science, 309(5738), 1190-1191.

5. Academy of Science of South Africa-ASSAf (2016).Women for Science: Inclusion and Participation in Academies of Science. Pretoria.ISBN978-0-9946852-0-9. Available at: http://www.assaf.org.za/index.php?option=com content\&view=article\&id=254:womenunderrepresented-in-world-science-report-finds\&catid=20:assaf-news\&Itemid=116. (Accessed 14 March, 2016).

6. Advancing Equality and diversity in Universities and colleges. http://www.ecu.ac.uk/equality-charters/athena-swan/. (Accessed 13 March, 2016).

7. Munir F (2014) Evaluating the effectiveness and impact of the Athena SWAN Charter Executive summary. Available at: http://www.ecu.ac.uk/wpcontent/uploads/external/evaluating-the-effectiveness-and-impact-of-the-athena-swancharter.pdf.

8. Science in Australia gender Equity (SAGE). Available at: http://www.sciencegenderequity.org.au/ . (Accessed 13 March, 2016).

9. Boyle PJ, Smith LK, Cooper NJ, O’Connor H, Williams K (2015) Women are funded more fairly in social science. Nature 525 (7568) 181-183.

10. Elsevier (2017). Available at https://www.elsevier.com/_data/assets/pdf_file/0008/265661/ElsevierGenderReport_fin al for-web.pdf 
11. Varella MAC, Ferreira JHBP, Pereira KJ, Bussab VSR, Valentova JV (2016) Empathizing, systemizing, and career choice in Brazil: Sex differences and individual variation among areas of study. Personality and Individual Differences 97, 157-164.

12. Chaimovich H \& Melcop PD (2007) Notas preliminares sobre financiamento à pesquisa no Brasil [Preliminary notes on research funding in Brazil]. Revista USP, (73), 6-23.

13. Oliva G \& da Silva FP (2012) Ciência e inovação [Science and innovation]. Revista USP (93) 59-68.

14. Alves AD, Yanasseb HH, \& Somac NY (2014) Perfil dos bolsistas PQ da área de Química baseado na plataforma Lattes. [Profile of CNPq productivity research fellows in the chemistry area based on the lattes platform] Quimica Nova, 37(2), 377-383.

15. Cavalcante RA, Barbosa DR, Bonan PRF, Pires MBDO, \& Martelli-Júnior, H (2008) Perfil dos pesquisadores da área de odontologia no Conselho Nacional de Desenvolvimento Científico e Tecnológico (CNPq) [Profile of dentistry researchers of the Brazilian National Research Council (CNPq)]. Revista Brasileira de Epidemiologia 11(1) 106-113.

16. Leite BD, Oliveira EA, Queiroz IN, Martelli DR, Oliveira MC, \& Martelli Júnior H (2012) Perfil dos pesquisadores com bolsa de produtividade no Conselho Nacional de Desenvolvimento Científico e Tecnológico (CNPq) da Área da Educação Física [Profile of the Researchers with Productivity Grants in the Brazilian National Research Council (CNPq) of the Physical Education Area]. Motricidade 8(3) 90-98.

17. Spilki FR (2013) Perfil dos bolsistas de produtividade do Conselho Nacional de Desenvolvimento Científico e Tecnológico $(\mathrm{CNPq})$ na área de Medicina Veterinária [Profile of the Conselho Nacional de Desenvolvimento Cientifico e Tecnologico (CNPq) productivity fellows in the area of Veterinary Medicine]. Pesquisa Veterinária Brasileira 33(2) 205-213.

18. Melo HPD \& Casemiro MCP (2003) A ciência no feminino: uma análise da Academia Nacional de Medicina e da Academia Brasileira de Ciência [Science in feminine: an analysis of the National Academy of Medicine and the Brazilian Academy of Sciences]. Revista Rio de Janeiro, Rio de Janeiro: UERJ (11).

19. Mendes PHC, Martelli DR \& Souza Filho WP (2010) Perfil dos pesquisadores bolsistas de produtividade científica na medicina no CNPq, Brasil. [Profile of Medical Researchers 
with Scientific Productivity Grants from the Brazilian National Research Council

511

512

513

514

515

516

517

518

519

520

521

522

523

524

525

526

527

528

529

530

531

532

533

534

535

536

537

538

539 (CNPq)] Revista Brasileira de Educação Médica 34(4) 535-541.

20. Martelli-Junior H, Martelli DRB, Quirino IG, Oliveira MCLA, Lima LS, \& Oliveira EAD (2010) Pesquisadores do CNPq na área de medicina: comparação das áreas de atuação. [CNPq researchers in medicine: a comparative study of research áreas]. Revista da Associação Médica Brasileira 56(4) 478-483.

21. Gonçalves E, Santos MIP, Maia BT, Brandão RCS, Oliveira EA, \& Martelli Júnior H (2014) Produção científica dos pesquisadores da área de pediatria no CNPq [Scientific research in pediatrics produced at the CNPq]. Revista Brasileira de Educação Médica 38(3): 349-355.

22. Oliveira E, Ribeiro A, Quirino I, Oliveira M, Martelli D, Lima L, Colosimo E, Lopes T, Silva A \& Martelli-Junior H (2011). Pesquisadores do Conselho Nacional de Desenvolvimento Científico e Tecnológico na área de Cardiologia. [Profile and Scientific Production of CNPq Researchers in Cardiology] Arquivos Brasileiros de Cardiologia 97(3) 186-93.

23. Barata RB \& Goldbaum M (2003) Perfil dos pesquisadores com bolsa de produtividade em pesquisa do CNPq da área de saúde coletiva [A profile of researchers in public healthwith productivity grants from the Brazilian National Research Council (CNPq)]. Cad. Saúde Pública 19(6): 1863-1876.

24. Leta J (2003) As mulheres na ciência brasileira: crescimento, contrastes e um perfil de sucesso. [The contribution of women in Brazilian Science: growth, contrasts, and a profile of success] Estudos Avançados, 17(49) 271-284.

25. Wendt GW, Lisboa, CSDM, De Sousa, DA \& Koller, SH (2013) Perfil dos Bolsistas de Produtividade em Pesquisa do CNPQ em Psicologia [The profile of scientific productivity of Brazilian Psychology research scholars of the Conselho Nacional de Desenvolvimento Científico e Tecnológico]. Psicologia: Ciência e Profissão 33(3) 536547.

26. Lists of scholarship holders are provided by CNPq. Available at http://plsq11.cnpq.br/divulg/RESULTADO_PQ 102003.curso http://www.cnpq.br/web/guest/bolsistas-vigentes. (Accessed 14 March, 2016). 
540

541

542

543

544

545

546

547

548

549

550

551

552

553

554

555

556

557

558

559

560

561

562

563

564

565

566

567

568

569

27. Lists of members were provided by the Brazilian Academy of Sciences. Available at: http://www.abc.org.br/rubrique.php3?id rubrique=54. (Accessed 14 March, 2016).

28. Edital Universal CNPq 2014 - lista de contemplados. [Lists of researchers awarded funding at: http://cnpq.br/chamadaspublicas?p_p_id=resultadosportlet_WAR_resultadoscnpqportlet_INSTANCE_0ZaM\&fil $\underline{\text { tro }=\text { resultados } \& \text { detalha }=\text { chamadaDivulgada\&idDivulgacao=4742. }}$. Accessed 14 March, 2016).

29. Pohlhaus JR, Jiang H, Wagner RM, Schaffer WT, \& Pinn VW (2011) Sex differences in application, success, and funding rates for NIH extramural programs Acad Med 86(6) 5967.

30. Bedi G, Van Dam NT \& Munafo M (2012) Gender inequality in awarded research grants. Lancet 380 (9840): 474.

31. Ceci, SJ, \& Williams, WM (2011) Understanding current causes of women's underrepresentation in science. Proceedings of the National Academy of Sciences, USA 108(8), 3157-3162.

32. Adamo SA (2013) Attrition of women in the biological sciences: Workload, motherhood, and other explanations revisited BioScience 63(1) 43-48.

33. Dutt K, Pfaff DL, Bernstein AF, Dillard JS, \& Block CJ (2016) Gender differences in recommendation letters for postdoctoral fellowships in geosciences Nature Geoscience 9(11) 805-808.

34. Su R, Rounds J, \& Armstrong PI (2009) Men and things, women and people: A metaanalysis of sex differences in interests Psychological Bulletin 135(6) 859-884.

35. Halpern DF (2013) Sex differences in cognitive abilities Psychology press

36. Lippa RA (2005) Gender, nature, and nurture Routledge

37. Cameron EZ, Gray ME, \& White AM (2013). Is publication rate an equal opportunity metric? Trends in ecology \& evolution 28(1) 7-8.

38. Glass JL, Sassler S, Levitte Y, \& Michelmore KM (2013) What's so special about STEM? A comparison of women's retention in STEM and professional occupations. Social Forces 92(2) 723-756.

39. Secretaria de políticas para as mulheres (2015). Programa Pró-Equidade 
570

571

572

573

574

575

576

577

578

579

580

581

582

583

584

585

586

587

588

589

590

de Gênero e Raça. Available at: http://www.spm.gov.br/assuntos/mulher-etrabalho/programa-pro-equidade-de-genero-e-raca/6-edicao. (Accessed 14 March, 2016). 40. Ministério das Mulheres, da Igualdade Racial e dos Direitos Humanos (2015) Revista do Observatório Brasil da igualdade de gênero. Available at: file:///C:/Users/MariaLuisa/Downloads/Revista\%20Observato\%CC\%81rio\%20\%202015 FINAL.pdf.

41. Nosek BA, Smyth FL, Sriram N, Lindner NM, Devos T, Ayala A, Bar-Anan Y, Bergh R, Cai H, Gonsalkorale K, Kesebir S, Maliszewski N, Neto F, Olli E, Park J, Schnabel K, Shiomura K, Tulbure BT, Wiers RW, Somogyi M, Akrami N, Ekehammar B, Vianello M, Banaji MR \& Greenwald AG (2009) National differences in gender-science stereotypes predict national sex differences in science and math achievement. Proceedings of the National Academy of Sciences, USA 106(26) 10593-10597.

42. Nosek BA, Banaji M, \& Greenwald AG (2002) Harvesting implicit group attitudes and beliefs from a demonstration web site. Group Dyn 6(1):101-115.

43. Kite ME, Deaux K, \& Haines EL (2008) Gender stereotypes. Psychology of women: A handbook of issues and theories, 2, 205-236.

44. Moss-Racusina CA, Dovidio JF, Brescoll VL, Graham MJ, \& Handelsman J (2012) Science faculty's subtle gender biases favour male students. Proceedings of the National Academy of Sciences, USA 109: 16474-16479.

45. Mühlenbruch B \& Jochimsen MA (2013) Research policy: Only wholesale reform will bring equality. Nature $49540-42$. 
592 Table 1. Distribution of the productivity scholarship holders by gender and sub-areas of

593 Engineering, Exact and Earth Sciences $(\mathrm{W}=$ Women, $\mathrm{M}=\mathrm{Men}, \mathrm{n}=$ frequencies, $\mathrm{AR}=$ Adjusted 594 residuals).

595

\begin{tabular}{|c|c|c|c|c|}
\hline Sub-areas & W (n) & $\mathbf{M}(\mathbf{n})$ & Total n & AR W \\
\hline Chemistry & 207 & 480 & 687 & 7.1 \\
\hline Chemical Engineering & 59 & 95 & 154 & 5.7 \\
\hline Industrial Design & 14 & 16 & 30 & 3.6 \\
\hline Nuclear Engineering & 25 & 48 & 73 & 3.0 \\
\hline Materials Engineering & 87 & 247 & 334 & 2.8 \\
\hline Sanitary Engineering & 36 & 88 & 124 & 2.5 \\
\hline Production Engineering & 26 & 62 & 88 & 2.2 \\
\hline Oceanography & 33 & 85 & 118 & 2.2 \\
\hline Computer Science & 88 & 287 & 375 & 1.7 \\
\hline Geosciences & 107 & 363 & 470 & 1.5 \\
\hline Probability and Statistics & 19 & 51 & 70 & 1.5 \\
\hline Transportation Engineering & 13 & 39 & 52 & 0.9 \\
\hline Civil Engineering & 56 & 210 & 266 & .4 \\
\hline Astronomy & 20 & 79 & 99 & .0 \\
\hline Aerospace Engineering & 10 & 44 & 54 & -.3 \\
\hline Mining Engineering & 4 & 21 & 25 & -.5 \\
\hline Marine Engineering & 1 & 10 & 11 & -.9 \\
\hline Biomedical Engineering & 4 & 60 & 64 & -2.8 \\
\hline Mathematics & 29 & 271 & 300 & -4.7 \\
\hline Mechanical Engineering & 24 & 252 & 276 & -4.9 \\
\hline Electrical Engineering & 13 & 269 & 282 & -6.7 \\
\hline Physics & 101 & 806 & 907 & -7.5 \\
\hline Total & 976 & 3883 & 4859 & \\
\hline
\end{tabular}


598 Table 2 - Distribution of the productivity scholarship holders by gender and sub-areas of Life 599 Sciences $(\mathrm{W}=$ Women, $\mathrm{M}=$ Men, $\mathrm{n}=$ frequencies, $\mathrm{AR}=$ Adjusted residuals $)$

\begin{tabular}{|c|c|c|c|c|}
\hline Subareas & W (n) & M (n) & Total n & $\mathbf{A R} \mathbf{W}$ \\
\hline Nursing & 165 & 8 & 173 & 14.7 \\
\hline Phonoaudiology & 50 & 1 & 51 & 8.3 \\
\hline Nutrition & 54 & 27 & 81 & 4.7 \\
\hline Public Health & 114 & 85 & 199 & 4.7 \\
\hline Microbiology & 105 & 82 & 187 & 4.2 \\
\hline Genetics, & 134 & 115 & 249 & 4.1 \\
\hline Botanics & 115 & 95 & 210 & 4.0 \\
\hline Immunology, & 90 & 69 & 159 & 4.0 \\
\hline Physiotherapy & 43 & 23 & 66 & 4.0 \\
\hline Pharmacy & 88 & 68 & 156 & 3.9 \\
\hline Food Science and Technology & 99 & 82 & 181 & 3.7 \\
\hline Pharmacology & 102 & 87 & 189 & 3.6 \\
\hline Morphology & 64 & 52 & 116 & 3.1 \\
\hline Biochemistry & 113 & 119 & 232 & 2.3 \\
\hline Physiology & 86 & 92 & 178 & 1.9 \\
\hline General biology & 4 & 1 & 5 & 1.8 \\
\hline Parasitology & 66 & 77 & 143 & 1.2 \\
\hline Odontology & 82 & 129 & 211 & -.7 \\
\hline Medicine & 205 & 333 & 538 & -1.6 \\
\hline Aquaculture & 22 & 47 & 69 & -1.6 \\
\hline Ecology & 68 & 126 & 194 & -1.8 \\
\hline Biophysics & 24 & 59 & 83 & -2.3 \\
\hline Fisheries Engineering & 28 & 79 & 107 & -3.2 \\
\hline Zoology & 64 & 157 & 221 & -3.8 \\
\hline Veterinary Medicine & 91 & 208 & 299 & -3.9 \\
\hline Physical education & 14 & 70 & 84 & -4.6 \\
\hline Forest Engineering & 26 & 121 & 147 & -5.9 \\
\hline Zootechnics & 59 & 195 & 254 & -6.0 \\
\hline Agricultural Engineering & 17 & 127 & 144 & -7.3 \\
\hline Agronomy & 157 & 604 & 761 & -12.4 \\
\hline
\end{tabular}


Total

3338

5687

600 
602 Table 3 - Distribution of the productivity scholarship holders by gender and sub-areas of the 603 Humanities and Social Sciences ( $\mathrm{W}=$ Women, $\mathrm{M}=$ Men, Total $\mathrm{n}=$ frequencies, $\mathrm{AR}=$ Adjusted 604 residuals)

605

Total

\begin{tabular}{|c|c|c|c|c|}
\hline Sub-areas & $\mathbf{W}(\mathbf{n})$ & $\mathbf{M}(\mathbf{n})$ & $\mathbf{n}$ & AR W \\
\hline Linguistics & 152 & 59 & 211 & 6.7 \\
\hline Social Service & 62 & 9 & 71 & 6.4 \\
\hline Education & 242 & 136 & 378 & 5.9 \\
\hline Information Science & 35 & 10 & 45 & 3.8 \\
\hline Psychology & 175 & 138 & 313 & 2.3 \\
\hline Art & 61 & 42 & 103 & 2.0 \\
\hline Letters & 126 & 102 & 228 & 1.7 \\
\hline Urban Planning & 44 & 33 & 77 & 1.3 \\
\hline Architecture and Urbanism & 54 & 42 & 96 & 1.3 \\
\hline Domestic Economy & 1 & 0 & 1 & 1.0 \\
\hline Anthropology & 74 & 66 & 140 & .8 \\
\hline Archaeology & 23 & 19 & 42 & .7 \\
\hline Tourism & 8 & 6 & 14 & .6 \\
\hline Communication & 61 & 61 & 122 & .1 \\
\hline History & 113 & 125 & 238 & -.7 \\
\hline Geography & 40 & 51 & 91 & -1.1 \\
\hline Theology & 2 & 5 & 7 & -1.1 \\
\hline Sociology & 88 & 106 & 194 & -1.3 \\
\hline Museology & 1 & 4 & 5 & -1.3 \\
\hline Law & 26 & 42 & 68 & -1.9 \\
\hline Political Science & 42 & 77 & 119 & -3.2 \\
\hline Management & 50 & 126 & 176 & -5.8 \\
\hline Philosophy & 22 & 111 & 133 & -7.8 \\
\hline Economics & 29 & 178 & 207 & -10.6 \\
\hline Total & 1531 & 1548 & 3079 & \\
\hline
\end{tabular}


607 Table 4. Distribution of the productivity scholarship (PS) holders by gender and scholarship level 608 ( $\mathrm{W}=$ Women, $\mathrm{M}=$ Men, $\mathrm{n}=$ frequencies, $\mathrm{AR}=$ Adjusted residuals)

Exact Sciences and Earth Sciences

\begin{tabular}{lcccccc} 
Level & W $(\mathrm{n})$ & $\mathrm{M}(\mathrm{n})$ & Total n & W (\%) & M (\%) & AR W \\
\hline PS-1A & 41 & 378 & 419 & $9.8 \%$ & $90.2 \%$ & $\mathbf{- 5 . 5}$ \\
PS-1B & 75 & 391 & 466 & $16.1 \%$ & $83.9 \%$ & $\mathbf{- 2 . 3}$ \\
PS-1C & 78 & 380 & 458 & $17.0 \%$ & $83.0 \%$ & -1.7 \\
PS-1D & 161 & 595 & 756 & $21.3 \%$ & $78.7 \%$ & 0.9 \\
PS-2 & 621 & 2139 & 2760 & $22.5 \%$ & $77.5 \%$ & $\mathbf{4 . 8}$ \\
Total & 976 & 3883 & 4859 & $20.1 \%$ & $79.9 \%$ &
\end{tabular}

Life Sciences

\begin{tabular}{lcccccc}
\hline Level & W (n) & M (n) & Total n & W (\%) & M (\%) & AR W \\
PS-1A & 132 & 393 & 525 & $25.1 \%$ & $74.9 \%$ & $-\mathbf{7 . 9}$ \\
PS-1B & 172 & 343 & 515 & $33.4 \%$ & $66.6 \%$ & $\mathbf{- 3 . 8}$ \\
PS-1C & 248 & 351 & 599 & $41.4 \%$ & $58.6 \%$ & 0.1 \\
PS-1D & 418 & 580 & 998 & $41.9 \%$ & $58.1 \%$ & 0.4 \\
PS-2 & 1379 & 1671 & 3050 & $45.2 \%$ & $54.8 \%$ & $\mathbf{6 . 4}$ \\
Total & 2349 & 3338 & 5687 & $41.3 \%$ & $58.7 \%$ &
\end{tabular}

Humanities and Applied Social Sciences

\begin{tabular}{lccrccc}
\hline Level & W (n) & M (n) & Total n & W (\%) & M (\%) & AR W \\
PS-1A & 126 & 143 & 269 & $46.8 \%$ & $53.2 \%$ & -1 \\
PS-1B & 158 & 132 & 290 & $54.5 \%$ & $45.5 \%$ & 1.7 \\
PS-1C & 154 & 113 & 267 & $57.7 \%$ & $42.3 \%$ & $\mathbf{2 . 7}$ \\
PS-1D & 219 & 262 & 481 & $45.5 \%$ & $54.5 \%$ & $-\mathbf{- 2}$ \\
PS-2 & 874 & 898 & 1772 & $49.3 \%$ & $50.7 \%$ & -0.5 \\
Total & 1531 & 1548 & 3079 & $49.7 \%$ & $50.3 \%$ & \\
\hline
\end{tabular}

609 
611 Table 5. Distribution of the members of the Brazilian Academy of Science by gender and area of 612 knowledge $(\mathrm{W}=$ Women, $\mathrm{M}=$ Men, $\mathrm{n}=$ frequencies, $\mathrm{AR}=$ Adjusted residuals $)$.

Area W M

(n) (n)

Total n W(\%) M(\%) AR W

$\begin{array}{llllll}44 & 450 & 494 & 8.9 & 91.1 & \mathbf{- 4 . 9}\end{array}$

Engineering, Exact Sciences and Earth $(54.9 \%)$

Life Sciences

$\begin{array}{llllll}76 & 296 & 372 & 20.4 & 79.6 & \mathbf{4 . 7}\end{array}$

$(41.4 \%)$

Humanities and Applied Social Sciences

$\begin{array}{llllll}6 & 27 & 33 & 18.2 & 81.8 & .7\end{array}$

Total

$\begin{array}{lll}126 & 773 \quad 899\end{array}$

613

614 
615 Table 6. Distribution of the members of the Brazilian Academy of Science who are Productivity 616 Scholarship Holders by gender and scholarship level ( $\mathrm{W}=$ Women, $\mathrm{M}=\mathrm{Men}, \mathrm{n}=$ frequencies, $617 \mathrm{AR}=$ Adjusted residuals).

\section{Exact Sciences and Earth Sciences}

\begin{tabular}{lcccccc} 
Level & W (n) & M (n) & $\begin{array}{c}\text { Total } \\
n\end{array}$ & W (\%) & M (\%) & AR W \\
\hline PS-1A & 17 & 137 & 154 & $11.0 \%$ & $89.0 \%$ & 0.7 \\
PS-1B & 3 & 27 & 30 & $10.0 \%$ & $90.0 \%$ & .0 \\
PS-1C & 0 & 13 & 13 & $0.0 \%$ & $100 \%$ & -1.2 \\
PS-1D & 4 & 18 & 22 & $18.2 \%$ & $81.8 \%$ & 1.4 \\
PS-2 & 2 & 42 & 44 & $4.5 \%$ & $95.5 \%$ & -1.3 \\
Total & 26 & 237 & 263 & & &
\end{tabular}

\section{Life Sciences}

Level W (n) $\quad \begin{array}{lllll}\text { M (n) } & \begin{array}{c}\text { Total } \\ n\end{array} & \text { W (\%) } & \text { M (\%) } & \text { AR F }\end{array}$

PS-1A

20

$99 \quad 119 \quad 16.8 \% \quad 83.2 \% \quad-2.8$

PS-1B

1317

$23.5 \% \quad 76.5 \%$

.0

PS-1C

1118

PS-1D

1322

PS-2

$17 \quad 25$

$38.9 \% \quad 61.1 \%$

1.6

Total

48

153201

\section{Humanities and Applied Social Sciences}

\begin{tabular}{lrrrrrr} 
Level & W (n) & M (n) & Total & W (\%) & M (\%) & AR W \\
PS-1A & 4 & 4 & 8 & $50.0 \%$ & $50.0 \%$ & .8 \\
PS-1B & 0 & 0 & 0 & - & - & \\
PS-1C & 0 & 1 & 1 & & $100 \%$ & -.9 \\
PS-1D & 0 & 1 & 1 & & $100 \%$ & -.9 \\
PS-2 & 1 & 1 & 2 & $50.0 \%$ & $50.0 \%$ & .3 \\
Total & 5 & 7 & 12 & & & \\
\hline
\end{tabular}


618

619 Table 7. Percentages of men and women among the members of the Brazilian Academy of

620 Sciences (ABC) divided into a younger group (30 - 50 years) and an older group (more than 50

621 years).

622

\begin{tabular}{|c|c|c|c|c|c|c|c|c|}
\hline \multirow[t]{2}{*}{$\begin{array}{l}\text { Age } \\
\text { categ } \\
\text { ories }\end{array}$} & \multicolumn{2}{|c|}{ Total N (\%) } & \multicolumn{2}{|c|}{$\begin{array}{l}\text { Engineering, } \\
\text { Exact and Earth }\end{array}$} & \multicolumn{2}{|c|}{ Life Sciences } & \multicolumn{2}{|c|}{$\begin{array}{l}\text { Humanities and } \\
\text { Applied Social }\end{array}$} \\
\hline & Men & Women & Men & Women & Men & Women & Men & Women \\
\hline $30-50$ & $\begin{array}{l}140 \\
(78.7)\end{array}$ & $\begin{array}{l}38 \\
(21.3)\end{array}$ & $\begin{array}{l}78 \\
(86.7)\end{array}$ & $\begin{array}{l}12 \\
(13.3)\end{array}$ & $\begin{array}{l}60 \\
(70.6)\end{array}$ & $\begin{array}{l}25 \\
(29.4)\end{array}$ & $\begin{array}{l}2 \\
(66.7)\end{array}$ & $\begin{array}{l}1 \\
(33.3)\end{array}$ \\
\hline$\chi^{2}$ & \multicolumn{2}{|c|}{$58.45 * * *$} & \multicolumn{2}{|c|}{$48.40 * * *$} & \multicolumn{2}{|c|}{$14.41 * * *$} & & 33 \\
\hline$>50$ & $\begin{array}{l}708 \\
(91.1)\end{array}$ & $\begin{array}{l}69 \\
(8.9)\end{array}$ & $\begin{array}{l}411 \\
(94.9)\end{array}$ & $\begin{array}{l}22 \\
(5.1)\end{array}$ & $\begin{array}{l}262 \\
(86.5)\end{array}$ & $\begin{array}{l}41 \\
(13.5)\end{array}$ & $\begin{array}{l}24 \\
(82.8)\end{array}$ & $\begin{array}{l}5 \\
(17.2)\end{array}$ \\
\hline & \multicolumn{2}{|c|}{$527.45^{* * *}$} & \multicolumn{2}{|c|}{$350.46 * * *$} & \multicolumn{2}{|c|}{$162.12 * * *$} & \multicolumn{2}{|c|}{$12.45 * * *$} \\
\hline
\end{tabular}

623 
624 Table 8. Distribution of gender by amount of funding in the UNIVERSAL MCTI / CNPQ CALL 625 - № 14/2014 in the major areas of knowledge: Humanities and Applied Social Sciences (HASS), 626 Life Sciences (LS) and Engineering, Exact Sciences and Earth Sciences (ETEC). (W = Women, $627 \mathrm{M}=$ Men, $\mathrm{n}=$ frequencies, $\mathrm{AR}=$ Adjusted residuals).

\section{Exact Sciences and Earth Sciences}

\begin{tabular}{lrrrrrr} 
Amount & W (n) & M (n) & $\begin{array}{c}\text { Total } \\
\mathrm{n}\end{array}$ & W (\%) & M (\%) & AR W \\
\hline 60-120 thousand reais & 38 & 152 & 190 & $20.0 \%$ & $80.0 \%$ & $-1,6$ \\
30-60 thousand reais & 76 & 231 & 307 & $24.8 \%$ & $75.2 \%$ &, 1 \\
less than 30 thousand reais & 172 & 492 & 664 & $25.9 \%$ & $74.1 \%$ & 1,2 \\
Total & 286 & 875 & 1161 & & & \\
& Life Sciences & & & \\
Amount & W (n) & M (n) & Total & W (\%) & M (\%) & AR W \\
60-120 thousand reais & 112 & 218 & 330 & $33.9 \%$ & $66.1 \%$ & $-3,3$ \\
30-60 thousand reais & 236 & 362 & 598 & $39.5 \%$ & $60.5 \%$ & $-1,5$ \\
less than 30 thousand reais & 503 & 593 & 1096 & $45.9 \%$ & $54.1 \%$ & $\mathbf{3 , 8}$ \\
Total & 851 & 1173 & 2024 & & &
\end{tabular}

\section{Humanities and Applied Social Sciences}

Amount

60-120 thousand reais

30-60 thousand reais

less than 30 thousand reais

Total
$\mathrm{W}(\mathrm{n}) \quad \mathrm{M}(\mathrm{n}) \underset{\mathrm{n}}{\mathrm{T}} \mathrm{T} \quad \mathrm{W}(\%) \quad \mathrm{M}(\%) \quad$ AR W

$\begin{array}{rrrrrr}25 & 37 & 62 & 40.3 \% & 59.7 \% & -1,8 \\ 86 & 78 & 164 & 52.4 \% & 47.6 \% & , 4 \\ 222 & 203 & 425 & 52.2 \% & 47.8 \% & , 8 \\ 333 & 318 & 651 & & & \end{array}$


630

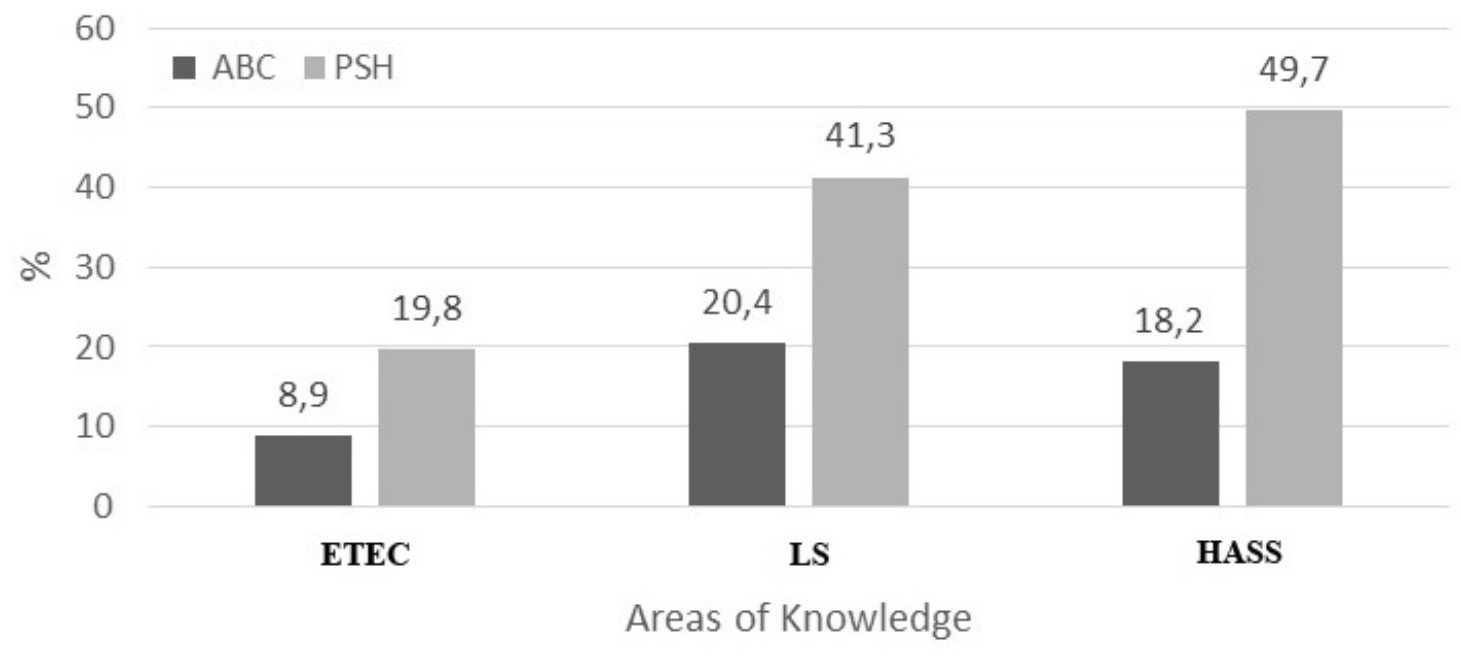

631

632 Figure 1. Comparative distribution of female researchers who are members of the Brazilian 633 Academy of Science (ABC - dark bars) and Productivity Scholarship Holders (PSH - light bars)

634 by areas of knowledge (ETEC $=$ Engineering, Exact Sciences and Earth Sciences, LS $=$ Life

635 Sciences, HASS = Humanities and Applied Social Sciences). The reverse percentages are 636 applicable for male researchers.

637

638 